\title{
Primetime Patriotism: News Media and the Securitization of Iraq
}

\author{
Ciaran O'Reilly \\ School of Politics and International Relations, University College Dublin \\ Room G310, Newman Building, UCD, Belfield, Dublin 4, Ireland \\ Tel: 35-38-7276-1567Ｅ-mail: ciaranoreally@gmail.com
}

\begin{abstract}
Predicated on a revision of the particular criteria for success, this article contends that the Iraq War was an example of successful securitization. It examines the role of the US news media in supporting the government's push for war in the context of heightened national feeling and patriotism after the events of 9/11.
\end{abstract}

Keywords: Securitization, Iraq, Critical Mass, News Media, Hyper-patriotism

\section{Introduction}

This paper aims to re-examine Buzan, Wæver and De Wilde's (1998) theory of securitization in light of the US war in Iraq. The processes which led to Iraq's status as a security threat are complex, and ones which Buzan et al's concept of securitization struggles to comprehensively explain. The $9 / 11$ attacks produced an inordinate level of national pride, sensitivity and public outrage within the United States which culminated in an atmosphere of hyper-patriotism. The fact that the media was both victim and contributor to this hyper-patriotism is integral to understanding its subsequent widespread support of the Bush administration's push for military action in Iraq. Therefore I hope to elaborate on Buzan et al's theory of securitization by looking at the role of the media as a functional actor. Further, I will strengthen the role of the audience beyond the implicit passivity of Buzan et al and consider the various interactions between public opinion, media and political elites which this raises. Incorporating much of Balzacq's (2005) ideas regarding securitization is key here, particularly with regard to his discussion of the congruent factors of audience and context. Balzacq recognizes much of the same shortcomings of Buzan et al, reflecting my central ideas in part but differing in others. My central argument is that while Buzan et al's theory of securitization remains core and fundamental, the exceptional circumstances leading to the war in Iraq have revealed new aspects of the process which require further study. In particular: the part of patriotism in allowing easier securitization of national security issues, the role of the media in contributing to this situation by becoming a temporary government mouthpiece in a time of perceived existential threat and the criteria of successful securitization. In regard to the latter, as opposed to popular opinion, this paper contends that the Iraq war was successfully securitized by convincing enough of the right people of its imminence as a threat, a concept I term critical mass and one on which I will elaborate first.

\section{Buzan to Baghdad}

Much has been said of the war in Iraq since it began in March 2003. While most seem to now accept that the reasons for the war were at best uninformed, there remain those of the US administration who remain adamant the cause was just and the reasons sound. These seem to be the kind of old guard that only retires in the grave. The actual securitization of Iraq has been put forward by most as a failure. A major part of this argument was the eventual US unilateral action, with the support of the UK and a few other nations, having failed to convince the majority of the international community and bypassing UN support and consent. The majority of the world's governments and their citizens remained highly skeptical of both the motives and claims of the Bush administration for the military action, with many claiming the real reasons ranged from so-called 'unfinished business' (much of George Bush Snr's staff redeemed their roles within his son's administration), to a grab for resources in the oil-rich country. Of course when it came to light that Iraq contained no Weapons of Mass Destruction (WMD) and thus did not represent an imminent or existential threat, the most fundamental aspect of any security threat and the subsequent reason for war was not produced. The Bush administration has since gone on to blame bad intelligence, and indicated the brutality of Saddam Hussein's regime as being as an equally just cause for war. This of course was not the stated motive before the conflict, and thus can be seen as a fallback position. This position itself is fairly untenable on any moral grounds, given the US support of numerous undemocratic regimes around the world. For example in the year before the Iraq war began, US political and economic support remained strong for Algeria - a regime documented by a leading human rights organization as unresponsive to and potentially directly responsible for numerous violations of basic human rights. Amnesty International noted that in Algeria in 2002 'the overwhelming problem of impunity for human rights violations continued to block the search for truth and justice in relation to the thousands of reports of torture, "disappearances" and killings committed by the 
security forces, state-armed militias and armed groups since 1992' (Amnesty International 2003). With hindsight, many who initially supported the war have since expressed regret and shame. What must not be forgotten however is that the war did go ahead, without military confrontation or political dissent strong enough to derail it. This paper will contend that the securitization of Iraq was in fact a successful one, based on a re-evaluation of the criteria of successfully securitization. Broadening out the examination to the entire process leading to the war, I hope to illustrate the pivotal role of news media, itself an area left ignored and underestimated by the securitization literature.

According to Buzan et al (1998), a security threat must be existential in nature in order to legitimize the use of special powers and military action, 'traditionally, by saying "security," a state representative declares an emergency condition, thus claiming the right to use whatever means are necessary to block a threatening development' (Wæver cited in Buzan et al, 1998: 21). What is the threat and what is its target have usually been states and their respective nations, considered to be part of the 'middle scale of limited collectivities' (Buzan et al, 1998). States exist largely within identity politics, strengthening their sense of self-perception and international role through contrasts with others, particularly perceived enemies. The campaign for supporting the war in Iraq was peppered with references to 'good' and 'evil' and most memorably, George Bush's 'crusade' speech (Der Derian 2002). Such framing of the issue helps to narrow the gap between citizen and state, identifying the security interests of the political elite with that of the country's citizens. This approach was particularly salient in the aftermath of $9 / 11$ as will be discussed throughout. It was a concerted 'hijacking' of national feeling and fostering of hyper-patriotism, driven through the mainstream media, which played upon the 9/11 attacks and created an audience far more susceptible to securitization rhetoric. It is essential therefore to examine the process of securitization itself and the relevant actors.

\subsection{Critical Mass}

Securitization is a speech-act, a process which performs while being said, i.e. an issue can become a security threat by virtue of having been described as such. Obviously, who makes such a claim and to whom is fundamental to this process. Buzan et al (1998) look not at whether genuine security risks exist but the process whereby something or someone is represented as such. The criteria which determine a securitizing move as being successful are fairly untreated by Buzan et al, other than a conclusion which speaks vaguely about the recognition of broken rules. I wish to elaborate further on this aspect to securitization with reference to Iraq, because it is vital to properly consider such a process without setting out how and why it achieves success. To facilitate this I have termed a concept of critical mass, which is the concept that securitization has been successful, i.e. critical mass has been achieved, when the securitizing actor has convinced enough of the right people that someone or something constitutes a legitimate security threat. There are two pillars to this process, namely volume and caliber. The first is simply the idea that a particular amount of people, usually the majority of the target group, must be convinced of the threat. This seems clear, given that convincing only a handful of US Senators or a small minority of the US public would almost certainly not have resulted in a war. The latter pertains to the appropriateness and relevance of the particular audience. It was essential above all else to convince the US Senate and American public of the threat Iraq posed rather than, for example, the people of Ireland. This is particularly so with regard to small or developing countries with little to offer in terms of military or political leverage. Each pillar is dependent on the specifics of any situation, but should be easily recognizable. The domestic/international dynamic of this concept is particularly relevant to the Iraq War. Winning the moral support of the American public and the formal support of a Senate vote went hand-in-hand, and arguably influenced each other in supporting the war. Support for the conflict outside the US was largely non-existent, though as we shall see later the US media's role in misrepresenting the international community's opinion was pivotal. I believe that Iraq was successfully securitized if one takes these criteria into consideration and accepts that while the majority of the international community was not convinced, this may not have been necessarily essential.

\subsection{Formalization}

The impetus to push support for the war through formal channels both in the US and at the UN may have seemed laborious and time-consuming given the malleable nature of public feeling. However this formalization is another key aspect of the critical mass concept, and one which gave the Bush administration four key advantages. First, they were seen as further differentiating themselves from the enemy, most notably Al-Qaeda, for respecting due process and the basics of democracy. Second, the inclusion of both parties via the Senate vote while technically necessary in order to wage war created an impression of political consensus and agreement on the issue for the wide public and media. Third, they were seen as having respect for the opinion and authority of the international community. Although soon after enough foreign states were in support of the US to circumvent UN procedure which was seen by many as an arrogant and hasty move. Last and most importantly, such formalization significantly resists challenges or charges of illegal action and/or war crimes in the future, should the military action become unpopular. This could come about either domestically or internationally based on new evidence, a perception of instability and ineptitude or a failure to achieve stated goals. Each of these four can be thought of in a broader context as elements of the securitization process which should be incorporated and considered when examining future empirical evidence. 


\section{Representation and Perception}

The Bush administration did enough of a job securitizing Iraq as to gain support from a significant majority of the US public, the US Senate and several other states including most importantly the United Kingdom. The entire process was also made easier by the environment or 'context' as Balzacq would describe it (Balzacq 2005). Specifically, I believe there is a direct correlation between levels of nationalism and patriotism and the ease by which a securitizing actor can successfully legitimize something or someone as a threat to national security. With this mind, I will turn to how the government achieved this, given the level of international opposition, with specific reference to the role played by both the intelligence community and mainstream US media, in the context of a national identity heavily influenced by the events of $9 / 11$.

\subsection{Audience and context}

Buzan et al's (1998) concept of security is somewhat narrow in its conception of the role of the referent object, i.e. the potential victim of the suggested threat. It fails to acknowledge that the referent object and the audience are often one and the same. The American public did not passively accept the words of the government simply because of the social status of the speakers or the passion of their delivery. The role of 'facilitating conditions' and 'functional actors' (Buzan et al, 1998) is understated and deserves far more consideration. Balzacq (2005) moves far more in this direction as he discusses the congruent forces of 'political agency, audience and context.' He takes Buzan et al as a platform from which he explores an area similar to my own; acknowledging the fundamental importance of Buzan et al's work while elaborating on its short-comings in order to ultimately strengthen the theory. Buzan et al's concept of intersubjectivity goes some way in approaching this process of multi-polar influence, but doesn't go far enough. Instead Balzacq's idea of the congruent forces of political agency, audience and context seem more appropriate in their realistic appraisal of the forces at work in securitization. Balzacq goes beyond a simple direct casual link between the securitizing efforts of the actor and the acceptance of the audience, which is often the referent object. Importantly however, as with Buzan et al, the specific role of the media is also understated. While it is appropriate to speak in theoretical terms of actors and context, if one is to understand real securitizing moves one must recognize the role of major actors such as the media. Given the part media plays in presenting government policy, its image as an unbiased representative of truth and its subsequent effect on public opinion, it is essential to examine its role in the process. There were many contributing factors beyond the media itself, most notably the national feeling of hyper-patriotism post-9/11, of which it was both victim and contributor. The increasingly competitive pressure to entertain and sustain high ratings within modern news media is also very pertinent. In particular the notion of trying to 'outfox Fox' (Cohen 2003) in being seen to be most patriotic is a salient phenomenon in this context.

In Buzan et al's terms I would describe the media as a major 'functional actor' whose role in Iraq demonstrates the kind of influence news media can have in the process of securitization. Equally, a 'facilitating condition' would be the hyper-patriotism prevalent throughout the country, which greatly increased the ease with which a military action, particularly one linked with 9/11, could be accepted and supported. Thus the 'context' as Balzacq (2005) describes it is an essential aspect to both the success of a securitizing move and the ways in which such a move is framed in order to take advantage of the zeitgeist. A subsidiary aspect remains security intelligence, and while its role was paramount with regard to Iraq war, I contend that it remains a smaller aspect of the authority and expert status of the main securitizing actors. By which I mean that security services provide the intelligence information on which policy is based. If achieved correctly this remains a relatively secretive and muted operation, with limited direct influence on the media or public opinion. Thus while I will discuss their role with reference to Iraq, the security services will be left aside as an understated but not essentially sui generis aspect of the securitization process itself, but something that perhaps requires further examination elsewhere.

\subsection{Interpretation and reaction}

While I accept Balzacq's notion of an external context with which a use must be aligned, I am reluctant to frame such a thought in concrete notions of a 'real' security threat, "In its attempts to follow a more radical approach to security problems wherein threats are institutional, that is, mere products of communicative relations between agents, the CS [Copenhagen School] has neglected the importance of 'external or brute threats', that is, threats that do not depend on language mediation to be what they are - hazards for human life," (Balzacq 2005: 181).

While some dangers exist in reality regardless of whether or not their existence is recognized, I would maintain that a speech-act remains in force in the sense of how such a threat is presented to an audience. Unless one stands by the shore waiting for rockets to come flying by, one gleans the existence of a threat real or perceived through the media. Depending on how a threat is framed, even if its results or effects remain unaffected, the response by the audience is still based on the speech-act of journalistic presentation. For example, if an American airplane was shot down by Russian forces and one network were to report the incident as an accident while another claimed it as a terrorist attack, the subsequent response by the viewers of each network would be vastly different. The real nature or motive of the attack has not been affected and of course cannot be, but the subsequent perception, response and reaction of the 
audience are based on such journalistic presentation. Indeed the study done in 2003 on misperceptions and the Iraq war by the Program on International Policy Attitudes (PIPA) and Knowledge Networks would seem to support my thesis. External context remains paramount because threats will always exist regardless of acknowledgment or acceptance, but the response and reaction to the threat by the referent object is nonetheless shaped by a speech-act, i.e. the framing of the threat by news media, the source from which the referent object learns of the threat's existence. In the PIPA/Knowledge Networks study an element of the methodology reveals a worldwide majority was opposed to the Iraq war (PIPA \& Knowledge Networks 2003). Could it be based on the variance in how Iraq was presented as a threat within US media compared to international news media sources? Can intelligence be to blame when all major international security services were under the same illusion as to the presence of WMD in Iraq?

"Of course, by virtue of 'good reasons' (i.e. the claim that they know more than they can say or the argument of secrecy) public officials would find it easier, compared to any other securitizing actor, to securitize an issue, primarily, because they hold influential positions in the security field based on their political capital, and have privileged access to mass media" (Balzacq 2005: 190, my emphasis).

Could it be perhaps because the world's media, without a US government influence or the context of 9/11, presented Iraq more realistically and truthfully? The singularity of hyper-patriotism within the US at that time must be taken into account to explore this further. The US government's use of media in convincing the American public was significantly based on this concept of perception and framing and an understanding of the power of the media to affect public opinion. It remains for individual networks and print media to reflect on their roles in misrepresenting the cause for war, and their motives for doing so.

Taking it further, the government who are in theory privy to all relevant information, are in a position to make what Buzan et al describe as a 'political choice' (Buzan et al 1998) to securitize something with a far more balanced opportunity than the general public. They have in theory been allowed to view all the intelligence data and been spared the inherent selectivity and framing of mainstream media, particularly any news media channels recognized as either right or left-leaning. This is premised on the notion of competent intelligence gathering of course, which in the case of Iraq was arguably non-existent. Depending on your source, one can conclude that the failure of the security services was anything from a vested interest in instigating war, pure ineptitude and human error or the result of heavy and consistent influence and pressure from policy-makers and members of the Bush administration. The impetus from the US government to produce evidence to support their war on Iraq seems to have incessant and unforgiving (Pillar 2006). Rather than creating policy based on intelligence produced in relative isolation, there is much to suggest that intelligence services were continuously guided in a particular direction, where it became apparent that only intelligence supporting Iraq as a threat would be accepted (Taylor 2007). The fundamental failure therefore of the security services was not the issue of WMD (although they were clearly mistaken on this issue) but rather for not taking a stronger stance and resisting the policy-makers. By putting their name to such intelligence they knowingly contributed to justifying government policy, misinforming media sources and thus indirectly shaping public opinion.

\section{Legacy of $9 / 11$}

Balzacq's (2005) concept of an externalist approach bears particular appropriateness in relation to the Iraq war when one incorporates the events of 9/11. The attacks of Al Qaeda on September $11^{\text {th }} 2001$ were extraordinarily daring and horrific. They shattered the notion of America's safety and distance from terrorism and redefined America's role within the international community. The immediate effect was to engender feelings of sadness, shock and outrage throughout the country and create a desire for vengeance. The subsequent military action in Afghanistan produced success in this new 'War on Terror,' a campaign and phrase born from Ground Zero. This national feeling had cemented into resentfulness; questions of confusion and vulnerability seemed on the minds of every American. Until that point the media may not have accurately portrayed the impact of US foreign policy across the world, particularly in the Middle East. An immediate effect of 9/11 was to create a stark diatribe which identified Al-Qaeda, groups like them, all Islamic militants, etc outwards in ever-widening circles, as 'evil' and 'hating freedom'. Any attempt at understanding their motives or examining the historical or political context, particularly with regard to the legacy and effects US foreign policy was usually dismissed as at best irrelevant and at worst, unpatriotic and treasonous.

"Questions about the root causes or political intentions of the terrorist acts have been either silenced by charges of 'moral equivalency' or rendered moot by claims that the exceptional nature of the act placed it outside political discourse: explanation is identified as exoneration" (Der Derian 2002: 102)

Much of this feeling permeated the media, which of course consists of journalists not immune to the effects of such national feeling. Within the media many sources saw fit to promote the patriotic anthem and government policy, or simply passively allow government intervention. Der Derian provides several examples of media manipulation by the administration following the attacks, particularly when the Afghanistan conflict was involved. These included varied campaigns of propaganda by the Orwellian 'Office of Strategic Influence' and the Defense Department (Der Derian 2002). Hyper-patriotism could perhaps be best defined as such a situation in which political dissent is seen by society as 
unpatriotic and/or treasonous. This hyper-patriotism was an environment in which securitization of Iraq was made immeasurably easier for the political and military elites. It is hard to imagine how the war could have been justified in an America in which the attacks had not taken place. Indeed, it is vital to note that during the campaign to securitize Iraq by the Bush administration, key figures made statements on several occasions suggesting a direct link between Saddam Hussein's regime and Al-Qaeda. To take one of many examples,

"One of the greatest dangers we face is that weapons of mass destruction might be passed to terrorists who would not hesitate to use those weapons. Saddam Hussein has longstanding, direct and continuing ties to terrorist networks. Senior members of Iraq intelligence and al Qaeda have met at least eight times since the early 1990s. Iraq has sent bomb-making and document forgery experts to work with al Qaeda. Iraq has also provided al Qaeda with chemical and biological weapons training. And an al Qaeda operative was sent to Iraq several times in the late 1990s for help in acquiring poisons and gases. We also know that Iraq is harboring a terrorist network headed by a senior al Qaeda terrorist planner." (George Bush 2003).

This is an essential component to the entire process because unlike Afghanistan, two years had passed since 9/11 and it was insufficient to simply state to need to invade Iraq and expect support. Indeed the success in Afghanistan was undoubtedly a contributing factor to the general faith and trust of the American people in the judgment and capability of both the administration and the armed forces. Hence there was a need to base the securitizing move on intelligence which suggested that Iraq held WMD and had maintained a link with Al Qaeda. Again my reasons for not overly focusing on the security services are because of the vast differences in the substance and nature of these two fundamental claims. The WMD were widely thought to exist by security services worldwide (the Blair's government's infamous 45 minutes scenario being a prime example), which was then discovered to be false. Importantly however the security services did not believe such weapons would be used against the United States, a fact that government officials and high-ranking administration personnel, including the President, chose to ignore. The link between Iraq and Al Qaeda remains the key issue and one which unfortunately seems to have been lost to collective journalistic amnesia, overshadowed by the ability to shift blame on the issue of WMD to the intelligence services. Importantly, many sources have revealed that from just days after 9/11, security services made it clear to the president that no such link existed between Iraq and the attacks. Regardless, what followed was a concise effort by government officials and high-ranking government members to misrepresent the relationship between Iraq and 9/11, to the point where a significant proportion of the American public believed such a link existed (Woodward 2004).

\section{Networking Patriotism}

While many of these inferences and claims were made in speeches from the President and Vice-President to the nation and hence unfiltered by media sources, the subsequent hours of discussion, debate and news coverage played a pivotal role. A PIPA (2003) study which correlates media source with misperceptions is staggering in its discoveries, and its conclusions are illuminating. Misperceptions, The Media and the Iraq War is an important piece of this puzzle which defines clearly the level and nature of the relationship between US mainstream media and the misperceptions regarding Iraq, on which much of the support for the war was based. Published in October 2003 after the war had officially ended, the report correlates three key perceptions about the Iraq war with the preferred news sources of the respondents. These three claims were that evidence of links between Iraq and al-Qaeda has been found; weapons of mass destruction have been found in Iraq; world public opinion favored the US going to war with Iraq. It concluded among other things that while perhaps expectedly Fox News viewers were the most uninformed, other mainstream 'liberal' media networks ranked close to and sometimes above Fox with regard to many misperceptions, having controlled for demographic differences within the viewing audiences. It also found a positive link between levels of misperception and support for the war (PIPA 2003). This is the key element of the study in that it establishes that news media can influence and in this case misinform public audiences with regard to an issue of national security. The subsequent viewing public has an opinion and attitude shaped by such media which directly affects the securitizing efforts of the actor, in this case the government.

What could be at work is the concept of 'manufacturing consent' and in particular the elite version, i.e. that 'news media coverage conforms with the interests of political elites, where elites are defined broadly as members of the executive, legislative or any other politically powerful group', (Robinson 1999). If we were to look at the UN response to the crisis in Darfur, it remained one of indifference until media and public outrage grew to what Robinson calls a 'crescendo' wherein the five permanent Security Council members were forced to act. The whole experience itself can be seen as an example of the influence of media in another area of international relations - principal-agent theory. Darfur serves to contrast starkly with the war in Iraq, a situation in which a government was pushing a policy and looking for public support, which was fostered and encouraged through the mainstream's presentation of government claims, the airing of key speeches and selective coverage. The latter was quite similar to the process of 'cherry-picking' known within intelligence services' circles (Taylor 2007). 


\subsection{The voice of the people}

To complete the circle it seems appropriate to look at the link between public opinion and policy, keeping in mind the more general notion of an audience's reaction to the securitizing actor and its effect on subsequent political policy. The war in Iraq required the moral support of the American people and to be seen to have that support. It is doubtful that the actual campaign specifics or tactics were in any way influenced by public opinion, but it remains worthwhile to examine the relationship as a whole. Shapiro and Page examined public opinion and policy data for the United States from 1935 to 1979 . With reasonable certainty they concluded that US policy including foreign policy has responded positively to public opinion, often within a lag of one year (Shapiro \& Page 1983). With that in mind, it is easy to understand the importance of winning the moral support of the American people in achieving a successful securitization of Iraq, and thus a major component of the critical mass. Americans who believed the US did the right thing by taking military action in Iraq has dropped from 64\% in December 2003 to 35\% in May 2007 (New York Times 2007).

\subsection{American exceptionalism}

The events of 9/11 and the ways it which shaped national identity in the following years were influenced by American exceptionalism, and the religious ideology underlying Al Qaeda's agenda. Securitizing actors combine 'collective memories' and 'general feeling' to redefine the nature of a threat to suit their aim, and to identify their own interests and security as being inseparable and integral to that of the referent object (Balzacq 2005). George Bush spoke often of 9/11 in the run-up to the war, and referred many times to the country's exceptional greatness and singularity within the international community. Media sources, and in particular the major television news networks, strived to show how patriotic they were, how proud they were to be American and most importantly how just was the cause for war.

"The mainstream media in the US reinforced this moralistic imagery by cheerleading the moves toward war and excluding any expression of dissenting or skeptical voices. This unconditional celebration of American life, values and institutions, without a scintilla of willingness to listen to anti-American grievances so prevalent in the Arab world and zero receptivity to self-criticism, had produced a patriotic fever with dangerous implications for Americans as well as others" (Falk 2002: 326).

Thus, through either professional laziness, naivety or conscious action the media can be said to have been somewhat of a mouthpiece for the Bush administration and had a direct link to the public's support for the Iraq war. The subsequent regret and remorse expressed by many media publications in recent months and years is proof of their self-awareness and reflective attitude (Washington Post 2004). The process of formalization is as mentioned earlier integral to the securitization process and in the case of Iraq was pursued both domestically and internationally. Former Secretary of State Colin Powell spent much time at the United Nations to compel those states of the Security Council to take stronger measures against Iraq in the hopes of preventing war (Woodward 2004). The majority of the administration however continued to push for war, as we have seen with regard to the intelligence community and the presentation and framing of Iraq by both the administration and mainstream media. Domestic support was formalized by a Senate vote in October 2002 which agreed to the use of US military action in Iraq (US Senate Legislation and Records 2002). This bipartisan agreement on the issue could have been interpreted as a move to put aside political disagreements for the greater good of the nation, something which undoubtedly must have impacted on a great many Americans. We saw a similar bipartisan effect within the mainstream media, as not just the traditionally conservative but the so-called 'liberal' sources joined the campaign to rally the nation towards this controversial war.

\section{Conclusion}

The shortcoming of Buzan et al (1998) is as Balzacq (2005) explains the lack of consideration of the influence of wider forces and context in the process of securitization. Balzacq's concept of the congruency of agency, audience and context goes a considerable way in elaborating on this and explains much of which Buzan et al fail to address. However, like Buzan et al, Balzacq does not go far enough in considering the nature of these actors within the process. The theory is an excellent template, one in which Buzan et al's ideas remain core, but the intertwining role of the media, the public and the state requires the focus for which I have strived. The state remains the most basic and common securitizing actor within security issues and the public remains its most common audience and referent object. As we have seen with the Iraq War, within this relationship the role of the media as provider of information, facilitator of communication between the two and bastion of truth and investigation is fundamental. It deserves far greater study that can be achieved here. Beyond the Iraq war, I hope to have put forward some noteworthy definitions, terms and examinations of securitization, such as the concept of critical mass and all its components. The criteria by which an issue is successfully securitized have hopefully been given more clarification, in addition to those steps taken by securitizing actors throughout the process. News media exists in a specific and trusted position within our society, in order that accountability and truth may be presented against the sometimes self-serving political motives of government and military powers. However in times of exceptional national threat, when a nation may regress to more defensive perceptions of themselves and their enemies, journalists too feel the effects. The personal feelings of vulnerability and distress combined with the expectations and competitive atmosphere of the profession can create a media more willing 
to shirk its responsibility to unbiased reporting. To thoroughly examine the role of news media as a functional actor and patriotism as a facilitating condition would add to the whole theoretical framework and allow for a greater understanding of empirical evidence in the future.

\section{References}

Amnesty International, Amnesty International Report, 2003, London, Amnesty International Publications.

Balzacq, T. 2005 'The Three Faces of Securitization: Political Agency, Audience and Context', European Journal of International Relations, vol. 11, no. 2, pp. 171-201.

Bush, G. President's Radio Address, February 2, 2003. Retrieved December 9, 2007, from http://www.whitehouse.gov/news/releases/2003/02/20030208.html.

Buzan et al 1998, Security: A New Framework for Analysis, London, Lynne Rienner Publications.

Cohen, J. 'Bush and Iraq: Mass Media, Mass Ignorance', Common Dreams News Center, December 1, 2003. Retrieved December 2, 2007, from http://www.commondreams.org/views03/1201-13.htm.

Der Derian, J. 2002 'In Terrorem' in Booth, K \& Dunne, T (eds.), Worlds in Collision: Terror and the Future of Global Order, pp. 101-117, Basingstoke, Palgrave.

Falk, R. 2002 'Testing Patriotism and Citizenship in the Global Terror War' in Booth, K \& Dunne, T (eds.) Worlds in Collision: terror and the future of global order, pp. 325-335, Basingstoke, Palgrave.

Kurtz, H. 2004 'New Republic Editors 'Regret' Their Support of Iraq War', The Washington Post, June 19, p. C01. Retrieved December 2, 2007, from http://www.washingtonpost.com/wp-dyn/articles/A53812-2004Jun18.html.

Liberto, J. 'Flags still wave, but sales fall from peak', St. Petersburg Times, 10 September, 2002. Retrieved December 3, 2007, from http://www.sptimes.com/2002/09/10/911/Flags_still_wave_but.shtml.

Page, B. I. \& Shapiro, R.Y. 1983 'Effects of Public Opinion on Policy,' The American Political Science Review, vol. 77, no. 1, pp. 175-190.

Pillar, P. 'Intelligence, Policy, and the War in Iraq', Foreign Affairs, March/April 2006. Retrieved December 2, 2007, from http://www.foreignaffairs.org/20060301 faessay85202-p0/paul-r-pillar/intelligence-policy-and-the-war-in-iraq.html.

PIPA/Knowledge Networks, 2003 'Misperceptions, the Media and the Iraq War'. Retrieved December 3, 2007, from http://65.109.167.118/pipa/pdf/oct03/IraqMedia_Oct03_rpt.pdf.

Robinson, P. 1999 'The CNN Effect: can the news media drive foreign policy?' Review of International Studies, vol. 25, pp. 301-309.

Sixty Minutes, 2004 'Woodward Shares War Secrets'. CBS News, April 18, 2004. Retrieved December 7, 2007, from http://www.cbsnews.com/stories/2004/04/15/60minutes/main612067.shtml.

Sussman, D. 2007 'Poll Shows View of Iraq War Is Most Negative Since Start', The New York Times, May 25. Retrieved December 4, 2007, from http://www.nytimes.com/2007/05/25/washington/25view.html.

Tapper, J. 'Senate Regrets the Vote to Enter Iraq', ABC News, 5 January, 2007. Retrieved December 3, 2007, from http://abcnews.go.com/GMA/Politics/story? Id =2771519\&page=1.

Taylor, S. A. 2007, 'The Role of Intelligence in National Security' in Collins, A (Ed), Contemporary Security Studies, Oxford, Oxford University Press.

US. Senate Roll Call Votes $107^{\text {th }}$ Congress - $2^{\text {nd }}$ Session. Retrieved December 3, 2007, from http://www.senate.gov/legislative/LIS/roll_call_lists/roll_call_vote_cfm.cfm? congress=107\&session=2\&vote=00237.

Wæver, O. 1995, 'Securitization and Desecuritization' in Ronnie D. Lipshutz (ed.), On Security, Columbia University Press, New York. 